SERĐO KOS, Ph.D. ${ }^{1}$

E-mail: skos@pfri.hr

LUKA VUKIĆ, mag. ing. admin. nav. ${ }^{2}$

E-mail: Ivukic@pfst.hr

(Corresponding author)

DAVID BRČIĆ, Ph.D. ${ }^{1}$

E-mail: brcic@pfri.hr

1 University of Rijeka, Faculty of Maritime Studies

Studentska 2, 51000 Rijeka, Croatia

2 University of Split, Faculty of Maritime Studies

Ruđera Boškovića 37, 21000 Split, Croatia
Transportation Economy

Review

Submitted: 31 May 2016

Accepted: 16 Nov. 2016

\title{
COMPARISON OF EXTERNAL COSTS IN MULTIMODAL CONTAINER TRANSPORT CHAIN
}

\begin{abstract}
The proposed paper discusses multimodal container transport due to savings in external costs. Relevant data have been analysed by reviewing previous research and published works for making a synthesis of one's own conclusions. The research findings showed that there is no significant difference in the share of external costs of container transport and transport of other types of cargo in great European seaports as well as in energy consumption of multimodal rail-inland ship container transport and the same transport mode of bulk cargo. Intermodal terminals have also their own external costs. In spite of a double railway operational cost, it is important to include the railway in the intermodal terminal. The inland waterway transport has much higher external costs than sea transport. Multimodal container transport does not necessarily lower external costs. The savings are more common if the location and type of intermodal terminal are selected properly, and the sea transportation is involved in the multimodal transport chain.
\end{abstract}

\section{KEY WORDS}

multimodal transport; container transport; external costs;

\section{INTRODUCTION}

Nowadays, international transport is based on complex networks of services that involve a plurality of stakeholders and transport solutions in order to make efficient connection between globalized origins and possible destinations $[1,2]$. The port efficiency and its competitiveness depend a lot on the connections between the port and its own hinterland [3].

External costs of transport are traffic caused social costs, which are not internalized in the transport sector, but compensated from other sources of public sector or community. They reflect the cost of all expenses that occur as a result of the exploitation of the transport system [4]. External transport costs are divided into three main categories: the cost of traffic accidents, the cost of pollution and the congestion costs [5]. In reducing the external costs it is important for transport users to be aware of the cost to society of their choice of transport mode. By calculating the external costs for each mode of transport the authorities can develop the strategic plan to redirect the transport to the environmentally more acceptable mode [6]. Based on the research by Digeisi et al. [8], it was concluded that the road sector generates $93 \%$ of total external costs, rail accounts for $2 \%$, the aviation passenger sector $4 \%$ and inland waterways $0.3 \%$. The same authors assert that the use of multimodal transport occurs with the reduction of external costs.

Multimodal transport reflects the combination of various modes of transport (water, road, rail and air), primarily through the use of containers. Containers allow safe transport and fewer risks [9]. Intermodal transport is a form of multimodal transport which is "the movement of goods in one and the same loading unit or road vehicle, which uses successively two or more modes of transport without handling the goods themselves in changing modes" [10]. Combined transport is intermodal transport mostly by rail, inland waterways or sea, and the road transport is reduced to the initial and/or final legs [12]. The road transportation included in multimodal transport chain shares in the external costs in a greater to a lesser degree. Environmental impacts of multimodal transport are lower than in road transportation which carries the negative social cost and perception [13]. There are efforts in EU transport policy to redirect road transport into a more acceptable transport mode [14].

Containerization is defined as "a method of distributing or transporting merchandise in a standard unit, thereby supporting an inter-modal transport system involving combinations of the road, rail and maritime modes" [15]. Container transport takes place within the road, rail, inland waterway, and maritime traffic networks. A node where the networks intersect is 
called the container terminal where the containers can be reloaded between different modes of transport [16].

The structure of this work consists of several authors' reports of the external costs in different types of freight transport and external costs in the multimodal freight transport with special attention to the share in the container transport. Although lower external costs are expected in multimodal transport, sometimes there are unexpected results as well. Analysing the previously published works, relevant data have been identified, elaborated and reasoned. The paper points out the conditions to be met in multimodal container transport chain in order to lower the share of external costs.

\section{EXTERNAL COSTS IN DIFFERENT TYPES OF FREIGHT TRANSPORT}

External costs are predominantly connected with road transport. According to the Austrian annual report 2005 [17] they were 11.6 times higher than in railway transportation and 15.4 times higher than in ship transportation (Figure 1). There are efforts to remove the freight from the roads as much as possible.

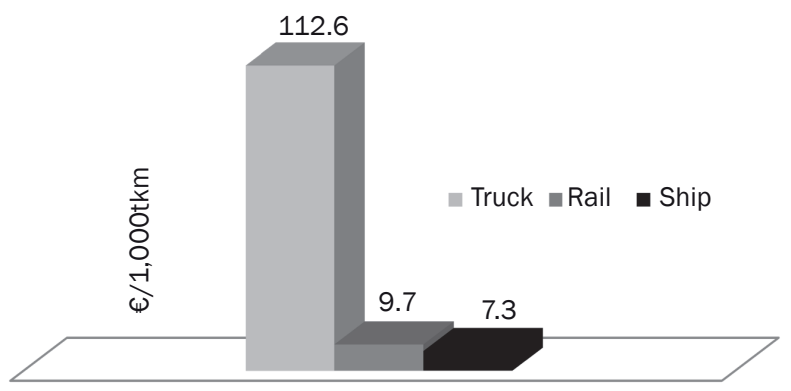

Figure 1 - Share of external costs in different types of freight transport

Source: [17]; modified

\subsection{Environmental impacts}

In total emission of transport-caused carbon dioxide $\left(\mathrm{CO}_{2}\right)$ in 2000 in Croatia, the road transport participated with $82.91 \%$, railway transport with $0.86 \%$ and all other transport modes with $16.18 \%$ [18]. According to EEA [19] in total transport sector emissions, the road transport participates with $83.33 \%$ of NMVOC, $55.55 \%$ of $\mathrm{PM} 2.5$, and $59.09 \%$ of PM10 emission. The share of rail transport is $<5 \%$ of both PM and absence of NMVOC emission. The share in SOx emission is negligible in both transport modes. Other environmental impacts of various transport types are shown in Figure 2.

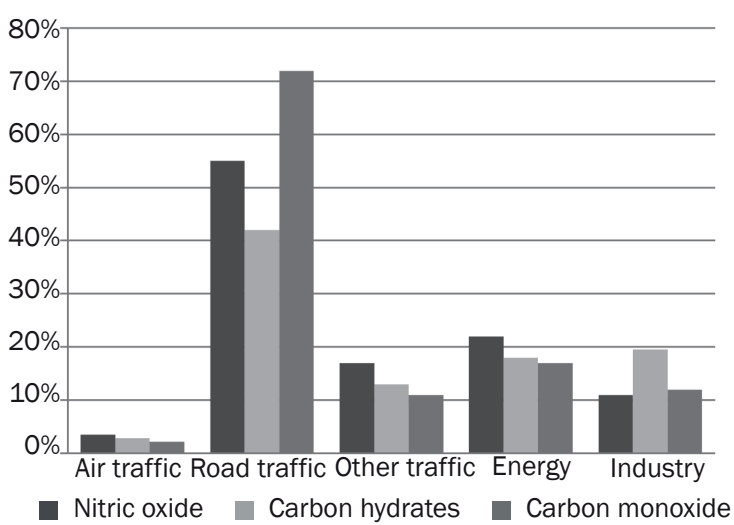

Figure 2 - Environmental impacts of various types of transport

Source: [20]; modified

\subsection{Congestion and accident related external costs}

Almost exclusively traffic congestion, accidents and respective external costs are connected with road transportation. In other kinds of transportation the accidents happen sporadically, and lately, there has been congestion, sometimes, in air traffic [20]. A share of these kinds of external costs in total transportation costs is significant and should be counted on them. As an example, the values of external costs of congestion in road transportation are graphically represented in Figure 3. They participated with $25-45 \%$ of total costs and amounted to $€ 2-15 / 1,000 \mathrm{tkm}$ [21]. The upper column indicates passenger traffic; the lower column refers to cargo transport.

Total internal and external costs of accidents in traffic are 3-4\% of GDP of a country [23]. According to CE Delft [11] the share of accidents of total road freight transport external costs was $€ 17 / 1,000 \mathrm{tkm}$. The external costs of accidents ( $t E C)$ are principally calculated by formula:

$t E C=P L+L L-P C$

where $P L$ reflects direct property losses; $L L$ reflects labour value losses, and $P C$ reflects internalized private costs. Direct losses are the values of lost properties. Labour value losses include the costs of total or partial impossibility of casualties to create the social value in the whole remaining labour ability period. Private costs include losses of life, losses of spirit and Social Service Agency Costs (Emergency Health Service, police, firemen, transportation, etc.). They are all internalized by means of insurance, so they can be taken away of the total external costs [24]. The average social accident costs in Croatia in 2010 were $€ 1,333,000$ for fatalities, $€ 173,300$ for severe injury and $€ 13,300$ for slight injury [25]. 


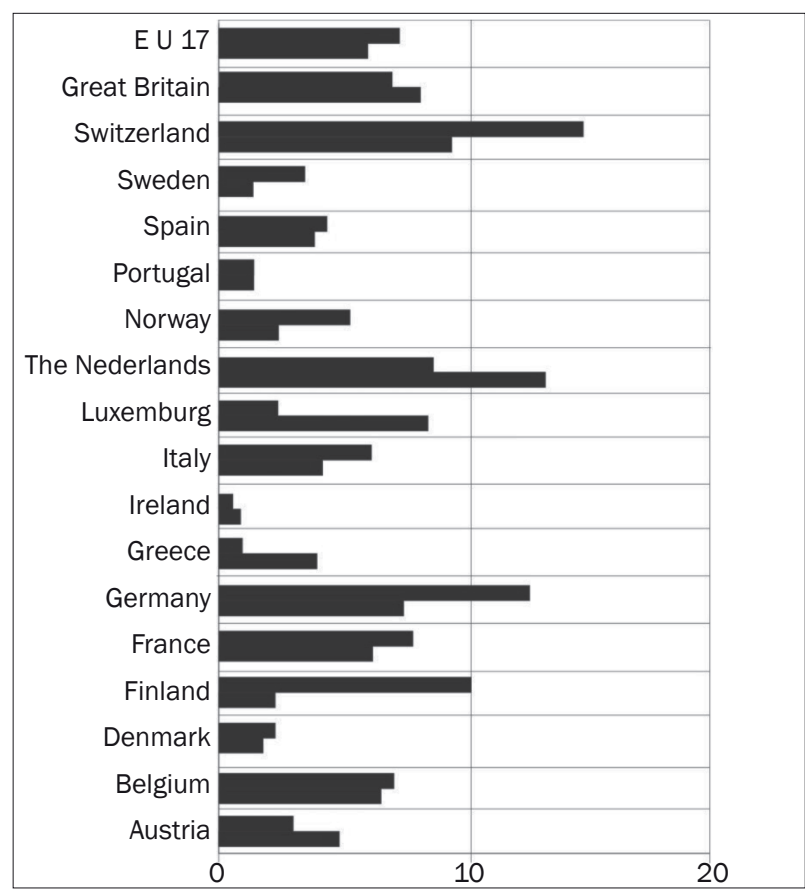

Figure 3 - External costs of congestion in Europe in 1995 Source: [22]; modified

\subsection{Share of external costs in freight transport}

The share of external costs in freight transport by cost category and mode are shown in Figure 4. There is the evidence (arrow) that the external costs of accidents participate only in road transport (€ 3.5/1,000tkm). The road transportation also predominates in air pollution.

Depending on various methodologies and taking into account various parameters, there are the values of external costs strongly different among different investigations (Table 1). However, all of them confirmed the need to shift the road transport into rail and waterways transport in order to make the external costs significantly lower. The costs of congestion are generally not taken into account and they are estimated in the range of $0.5-3.7 \%$ of GDP [27]. It is also important to note that inland waterways' external costs are significantly higher than in sea transportation. The values of external costs depend on characteristics of each line for which they are calculated.
The share in the percentage of external costs in various transport show predomination of road transport in the range of $60.1-87 \%$ (Table 2).

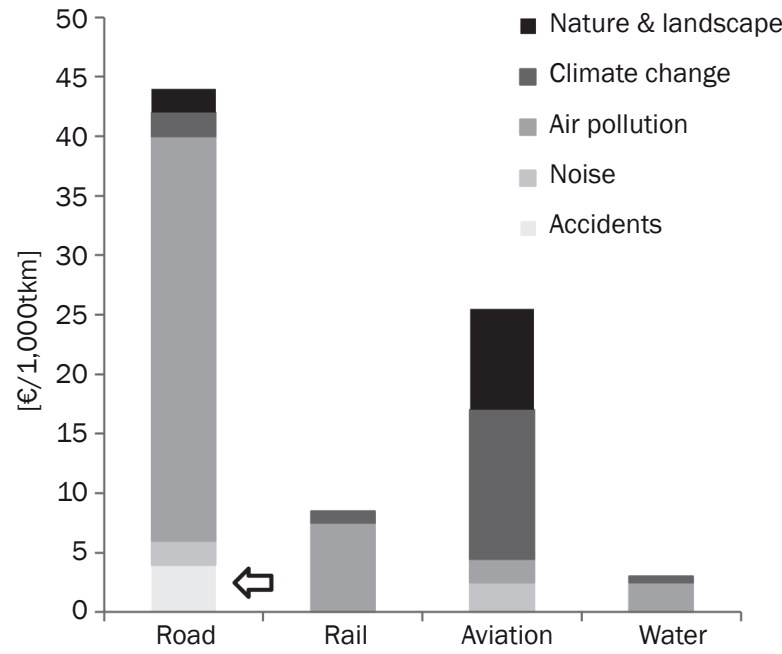

Figure 4 - Average external costs of freight transport by cost category and mode Source: [26]; modified

Table 2 - Share of external costs in different types of freight transport

\begin{tabular}{|c|c|c|c|c|}
\hline \multirow{2}{*}{$\begin{array}{c}\text { Transport } \\
\text { branch }\end{array}$} & \multicolumn{4}{|c|}{ External costs [\%] } \\
\hline & $\begin{array}{l}\text { UIC } \\
{[6]}\end{array}$ & $\begin{array}{l}\text { Bäck et } \\
\text { al. [17] }\end{array}$ & $\begin{array}{l}\text { Wei } \\
\text { [29] }\end{array}$ & $\begin{array}{c}\text { Hinšt } \\
{[21]}\end{array}$ \\
\hline Road & 83.7 & 87.0 & 60.1 & 68.5 \\
\hline Air & 14.0 & & & \\
\hline Railroad & 1.9 & 7.5 & 38.2 & 14 \\
\hline Water & 0.4 & 5.6 & 1.8 & \\
\hline Inland water & & & & 17.6 \\
\hline
\end{tabular}

\subsection{External costs in container transport}

Although external costs of container railway transport in EU are relatively low (€ 3-5/1,000tkm) and there are benefits from absence of congestion and accidents, they are actually much higher because of external costs of hinterland container terminals [30]. Similarly, seaway container transport has $66 \%$ higher external costs than seaway bulk transport [31]. Container vessels have short port stays, but produce high emissions during their stays [32].

Table 1 - Share of external costs in different types of freight transport

\begin{tabular}{||l|c|c|c|c|c||}
\hline \multirow{2}{*}{\multicolumn{1}{|c|}{ Transport branch }} & \multicolumn{5}{c||}{ External costs [€/1,000tkm] } \\
\cline { 2 - 7 } & Hinšt [21] & Bäck [17] & Maibach [28] & Ortolani [30] & Wei [29] \\
\hline \hline Road & 87.8 & 112.6 & 88 & & 12.6 \\
\hline Railroad & 17.9 & 9.7 & 19 & $3-5.6$ & 8 \\
\hline Inland waterways & 22.5 & & & & \\
\hline Sea waterways & & 7.3 & 12 & & 0.36 \\
\hline
\end{tabular}




\section{EXTERNAL COSTS IN MULTIMODAL FREIGHT TRANSPORT}

According to research by Burkhard et al. [33] multimodal transport reduces the number of accidents in the range of $60-80 \%$ as well as the emission of $\mathrm{CO}_{2}$ by $40-50 \%$. There is a benefit in marginal social costs of $33-72 \%$. The principle and final calculation of external costs should be carefully considered. Principally, there are benefits of multimodal transport as results of data shown in figures and tables. Practically, they depend on the line, distance, frequency, type of freight, shape of freight, mode of multimodal transport and type and location of the intermodal terminal. Smaller share of road transport leads to less external costs but not always and not unlimited. The evidence will be shown in examples of various modes of multimodal transport.

\subsection{Multimodal transport - mode railway instead of road transport}

According to Ortolani et al. [30] in three cities and surrounding region in Northern Italy collecting and disposal of industrial liquid waste were completely designed as road transport network. After changing the mode of transport, including rail, the road transport was reduced up to $60 \%$. The benefits are shown in Figure 5 . Total costs were $24 \%$ lower exclusively for lower external costs even on short distances. The saving was made by lower cost of the environment and congestion. However, increasing the share of rail transport over $40 \%$, the costs of the environment also rose due to "operating between three train stations close to the disposal centers". It shows how the direction of the line can influence the external costs in multimodal transport.

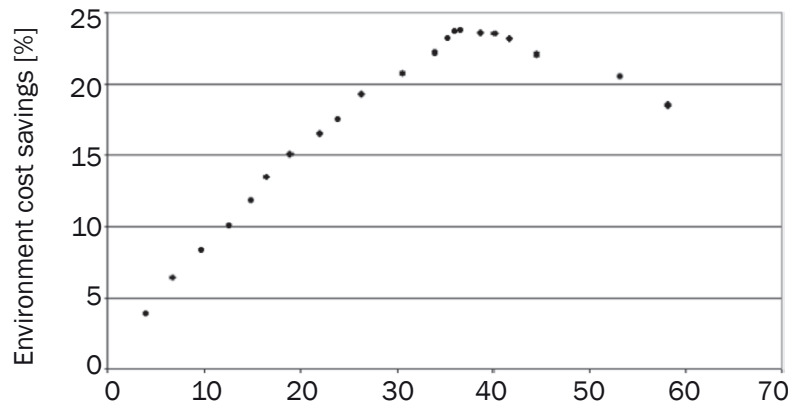

Transport by train on total [\%]

Figure 5 - Environmental cost savings vs. Rail transport ratio

Source: [30]

\subsection{Multimodal container transport -road-rail mode with intermodal rail terminal}

In research done by Janic [34] a cost-benefit analysis was used to investigate the differences between exclusively container road transport and intermodal road-rail container transport. The results are presented in Figure 6. They depended on the distance and frequency.

The internal costs of both transport means became equal at the distance of $900 \mathrm{~km}$, and the total cost equalized after $1,000 \mathrm{~km}$ if the frequency of trains is 5 per week. It means that the external costs of intermodal transport on a distance of more than $800 \mathrm{~km}$ were still higher than in road transport. With the frequency of 25 trains per week, equal cost point is moved at $200 \mathrm{~km}$ beforehand. High railway multimodal transport costs are the result of double operational costs of rail: operational costs of transport and the terminal.

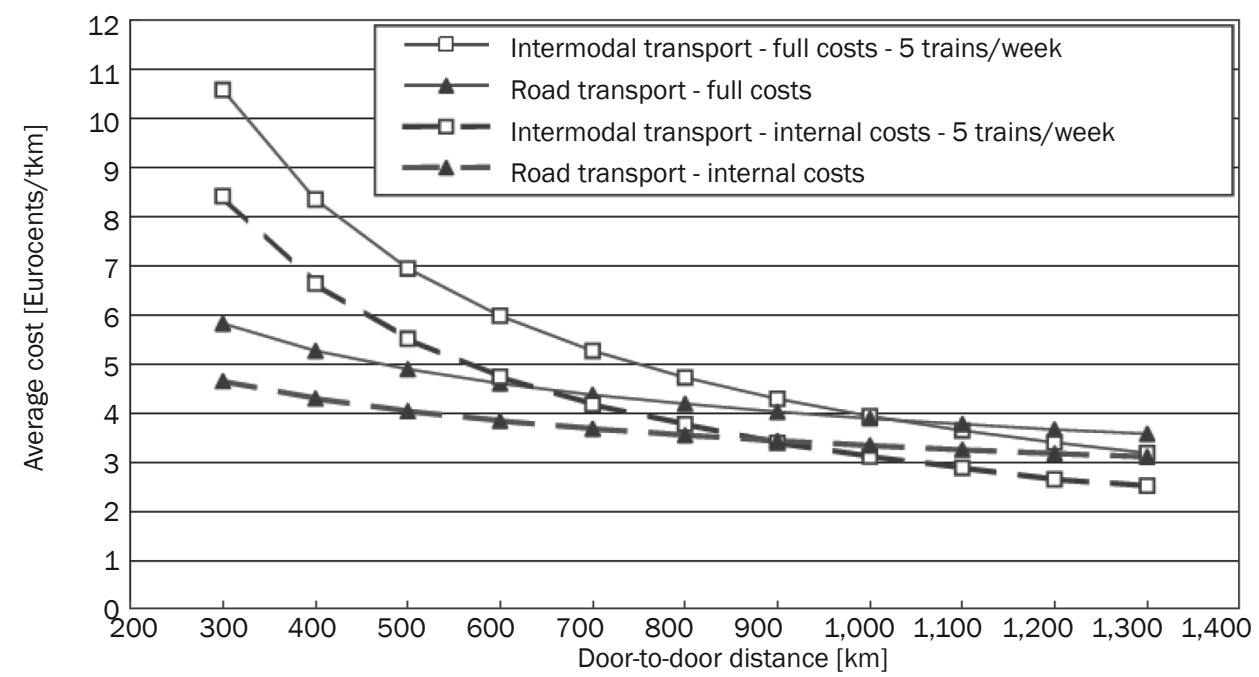

Figure 6 - Dependence of the average external, internal and full costs of given intermodal and road transport network on the door-to-door distance

Source: [34] 


\subsection{Multimodal transport - potential savings in the mode sea-rail instead of sea-road}

In a ten-year analysis by Rožić et al. [35] container transport growth in the Port of Rijeka, Croatia and the share of rail container transport are shown (Figure 7). Despite strong growth of total throughput of containers in the Port of Rijeka, the railway container transport has remained practically the same for years. The potential annual benefit of future inland container terminal of the Port of Rijeka is shown in Table 3. Annual savings would be $€ 4$ million on Rijeka - Hungarian border route and additional $€ 4$ million on Rijeka - Serbian border route. The results show the importance of inland container terminal in savings of external costs despite the costs appearing on the terminal itself.

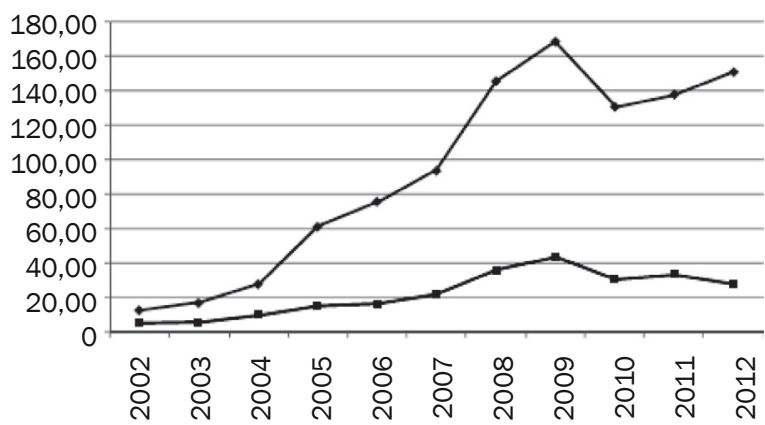

$\rightarrow$ Total throughput of containers in Port of Rijeka $\rightarrow$ Share of raillway container transport in Port of Rijeka

Figure 7 - Review of total throughput of containers and share of railway container transport in the Port of Rijeka Source:[35]

Table 3 - Total annual cost saving of container transport by rail after inland terminal construction (in €)

\begin{tabular}{||l|r|l|r||}
\hline \hline \multicolumn{1}{|c|}{ Location } & \multicolumn{1}{|c|}{ Amount } & Location & \multicolumn{1}{c|}{ Amount } \\
\hline \hline Delnice & 0 & Čačinci & $3,326,126.98$ \\
\hline Ogulin & 0 & Varaždin & $3,498,670.97$ \\
\hline Karlovac & $20,190.21$ & $\begin{array}{l}\text { Slavonski } \\
\text { Šamac }\end{array}$ & $3,584,193.66$ \\
\hline Zagreb & $59,780.16$ & Čakovec & $3,839,621.59$ \\
\hline Dugo Selo & $306,443.58$ & Tovarnik & $3,951,481.34$ \\
\hline Sisak & $780,622.382$ & Županja & $4,224,779.78$ \\
\hline Kutina & $1,028,389.19$ & Osijek & $4,234,615.03$ \\
\hline Bregi & $2,032,161.70$ & Vinkovci & $4,319,677.86$ \\
\hline Koprivnica & $2,198,688.08$ & Nemetin & $4,502,090.42$ \\
\hline $\begin{array}{l}\text { Slavonski } \\
\text { Brod }\end{array}$ & $2,427,483.71$ & Drenovci & $4,599,470.09$ \\
\hline Virovitica & $2,729,961.36$ & Knin & $6,992,365.14$ \\
\hline Volinja & $2,779,081.80$ & Solin & $10,078,457.90$ \\
\hline \multicolumn{1}{|l|}{} & Split & $10,082,991.10$ \\
\hline \hline
\end{tabular}

Source: [35]; modified

\subsection{Multimodal transport -road-sea mode with road container terminal instead of road}

According to Kotowska [36] the investigation estimates the impact of container terminals to reduce the external costs of transport for the Ports of Gdansk, Gdynia and Szczecin on the route towards Hamburg. The externalities are shown in Figure 8.

Considering pollution, the benefits do not arise from the reduction in emissions but are less harmful to society because they are away from residential areas. Moreover, the emissions of nitric oxides (NOx), sulphur oxides (SOx) and particulate matters (PM) were higher in land-sea transport chain. Particularly large benefits result from the smaller $\mathrm{CO}_{2}$ emissions, the number of road accidents and road congestion in the examined land-sea transport chains, as compared to competitive road transportation. The total savings of external costs are over 100 million euro per year, which is enough to build a new small container terminal. The terminal produces damages of large emissions of NOx. The results of research actualize the importance of the location of the intermodal terminal as well as the route of multimodal transport chain in the light of external costs.

\subsection{Limitations of multimodal container transport}

The articles taken by NEA et al. [37] and Caris et al. [38] show the structure of road transport costs where congestion and accidents have a significant share. In spite of this, the total costs were principally not higher than rail transport because there were great railway infrastructure costs (Figure 9). The air pollution of Rhine waterway transport (black) was the same as road or rail diesel transport. Lower costs in multimodal transport cannot be expected if sea transport is not included in the transport chain network.

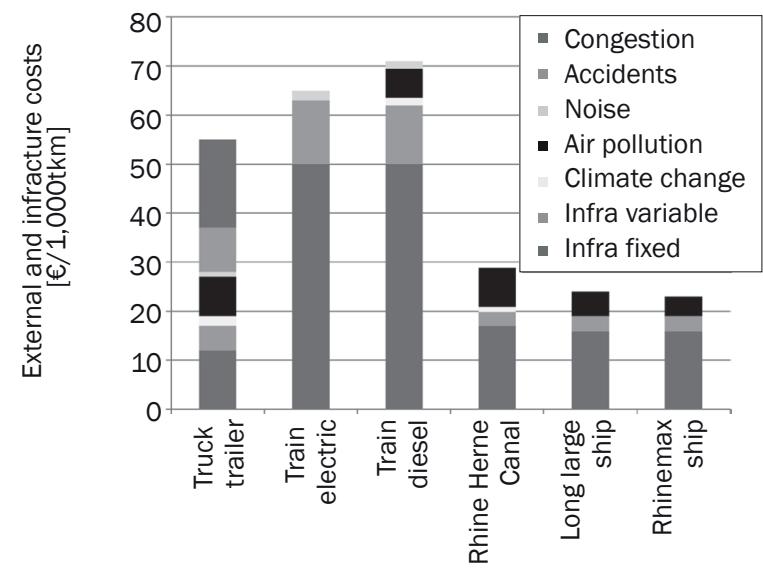

Figure 9 - External and infrastructure costs of container transport

Source: [37]; modified 

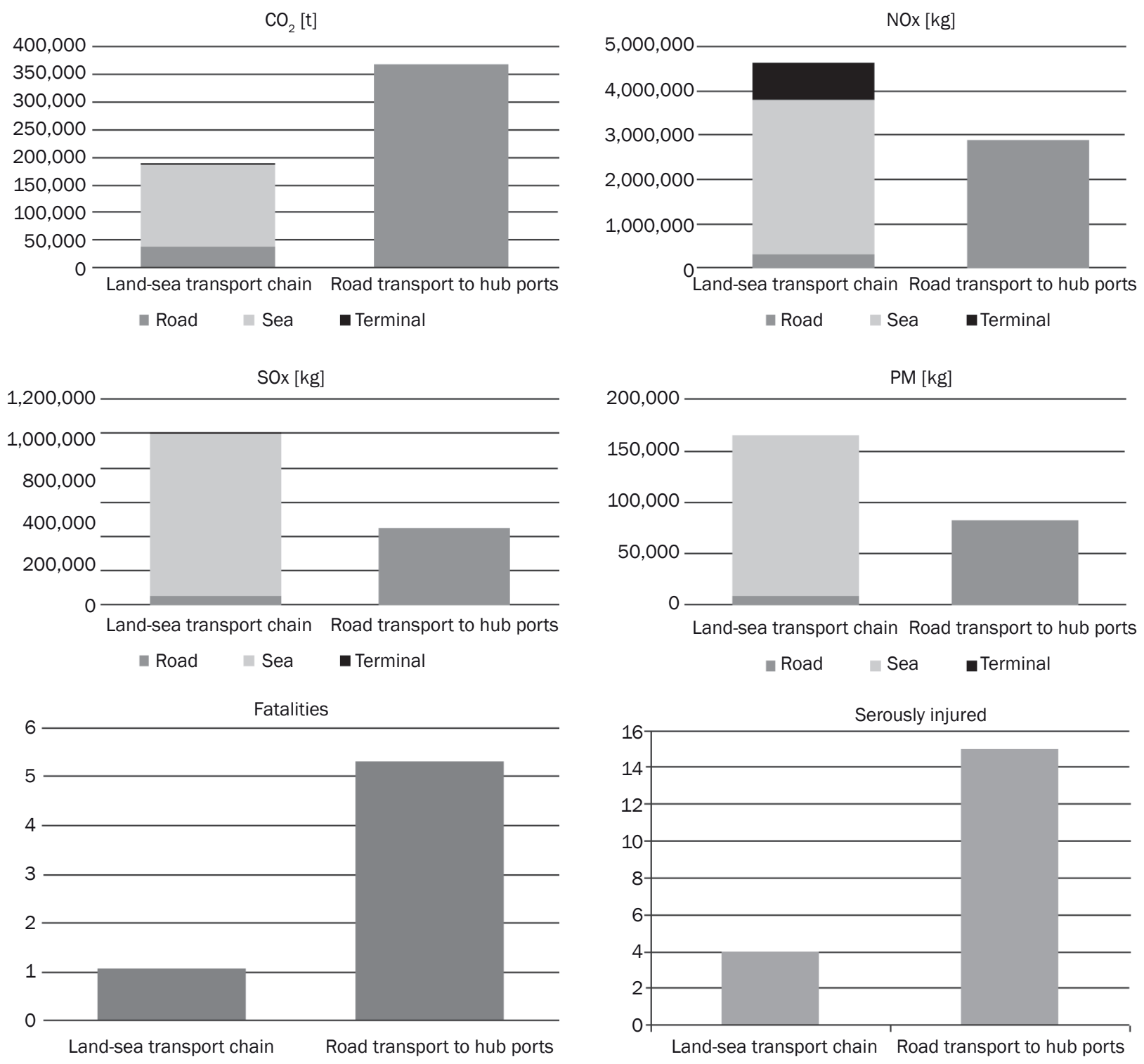

Figure 8 - Pollution, fatalities and serious injuries in tested road transport and alternative land-sea chain Source: [36]

\subsection{Share of external costs of multimodal container transport}

According to the research of PLANCO [39] the energy consumption for bulk and container transport is shown in Figure 10. Energy consumption in multimodal rail-inland ship transport of bulk and container cargo is equal. Inland waterways container transport cost is lower than competitive mode but the external costs of air pollution rise to $90 \%$ while road and rail are only $25 \%$ and $17 \%$, respectively. External cost calculation requires taking into account as many variables as possible to get a real frame for making decisions.

In the research taken by Meersman et al. [40] the external costs are calculated and compared according to the type of transported cargo in big European ports.

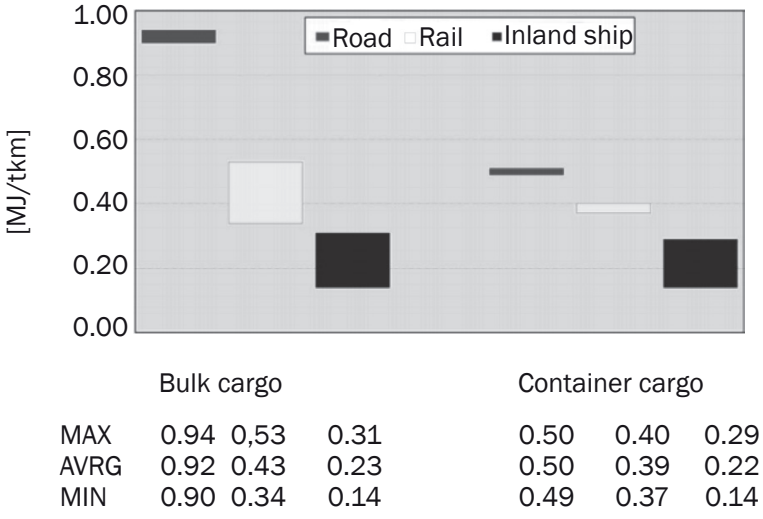

Figure 10 - Spread and averages of primary energy consumption on selected transport relations Source: [39] 
Based on the results it can be concluded that there is no significant difference in the share of external costs of container transport and transport of other types of cargo in big European ports. All of them accounted for about $50 \%$ of total costs (Table 4 ).

Table 4 - Share of external costs of container transport and other freight transport in the Port of Antwerp and the Port of Bordeaux

\begin{tabular}{||l|c|c||}
\hline \multirow{2}{*}{\multicolumn{1}{|c|}{ Cargo }} & \multicolumn{2}{c||}{ External costs [\%] } \\
\cline { 2 - 3 } & Antwerp & Bordeaux \\
\hline \hline Container & 46 & 54 \\
\hline General cargo & 52 & 52 \\
\hline Dry bulk & 49 & 55 \\
\hline Liquid bulk & 53 & 50 \\
\hline \hline
\end{tabular}

Source: [40]; modified

\subsection{Intermodal terminal}

The benefit of inland container terminal lies not in the lower pollution level but in the displacement of the pollution out from the urban area. Lower external costs arise from lower congestion and smaller consequences of accidents [38]. Climate change costs are expected to increase for all modes between 2009 and 2020. Although $\mathrm{CO}_{2}$ emissions per ton kilometre decrease for all modes, this is outweighed by the increase in the shadow price of $\mathrm{CO}_{2}$. For accident costs, the expected relative reduction is the same for road and rail transport (9\%). The total external costs per ton kilometre decrease by $8 \%$ for road transport, while for rail and inland waterway transport a smaller reduction of $1-2 \%$ is estimated, especially caused by the smaller reduction in air pollution costs of these latter modes compared to road transport [37]. According to Sulbaran and Sarder [41] it is of great importance for the railway to be included in the intermodal terminal. If so, the emissions are much lower, especially of NOx, PM10, PM2.5, carbon monoxide (CO) and reactive organic gas (ROG), so the external costs are also lower (Figure 11).

Rudolf [42] considers that in general, for container terminals, nearly $80 \%$ of the costs are independent of the number of ships and the volume of the handled merchandise. For bulk merchandise, fixed costs are lower and represent $60 \%$ of the invariable costs with the volume [43]. Several pieces of evidence show how well-connected hinterlands might increase port competitiveness [1] and how the organization of intermodal transport might enlarge port catchment areas [44]. The location and the organization of logistics parks or inland ports and the accuracy in designing a logistic system can significantly reduce the external costs in transport [45]. It can also make a significant long-term sustainable influence both on economy and the environment [46].

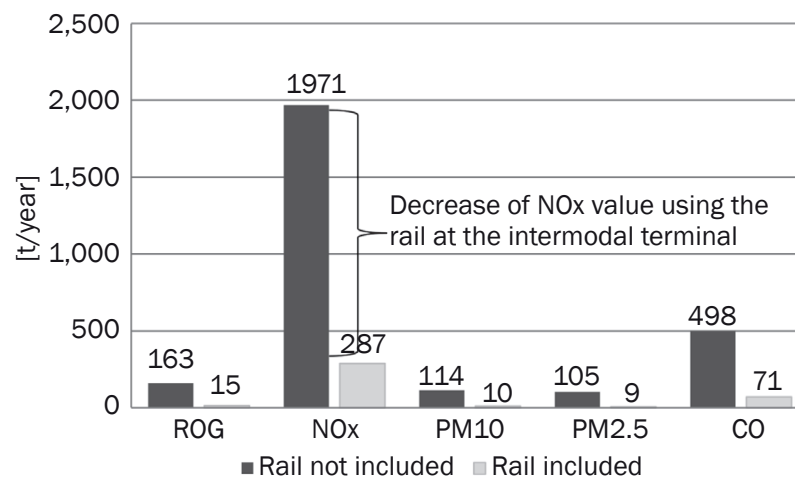

Figure 11 - Study of intermodal terminals Source: [41]; modified

\section{CONCLUSIONS}

The share of external costs in multimodal container transport chain has been investigated to find out which of the requirements should be met to keep it as low as possible. It was also important to show the limits of this kind of transport. Multimodal container transport does not necessarily lower the external costs. An intermodal terminal as part of multimodal transport has its own external costs which should be considered. In case of road intermodal container terminal, external costs will hardly be lower. Neither will the railway intermodal container terminal in road-rail mode significantly lower the costs, especially on distances shorter than $1,000 \mathrm{~km}$. There is a double railway operational cost: transportation and terminal cost. Sometimes, the environmental costs rise if the share of railway transport exceeds the limits defined by characteristics of the line. However, if the sea transport is included in multimodal transport chain, the savings will be significant, as opposed to the inland waterway transport.

According to cited authors there was no significant difference in the share of external costs of container transport and transport of other types of cargo in big European ports accounting for $50 \%$ of total costs. Energy consumption in multimodal rail-inland ship transport of bulk and container cargo was also approximately equal. There is some evidence of seaway container transport to have $66 \%$ higher external costs than seaway bulk transport. They are mostly connected with intermodal container terminal especially if located in port areas. As for rail, the emissions are significantly lower if the freight station is included/situated in the terminal. The multimodal container transport key factor is the type and the location of the intermodal terminal in the hinterland. Most savings come from re- 
duced congestion and accident costs as well as from the displacement of emission sources. The parameters for the intermodal terminal location choice become a challenge for future investigation research. Including sea transportation and minimizing road transportation in multimodal transport chain, significant savings can be expected. In this respect, the maritime transport would be able to play an increasing role.

The values of external costs depend on the characteristics of each line for which they are calculated.

\section{Dr. SC. SERĐO KOS ${ }^{1}$}

E-mail: skos@pfri.hr

LUKA VUKIĆ, mag. ing. admin. nav. ${ }^{2}$

E-mail: Ivukic@pfst.hr

Dr. sc. DAVID BRČIć ${ }^{1}$

E-mail: brcic@pfri.hr

${ }^{1}$ Sveučilište u Rijeci, Pomorski fakultet

Studentska 2, 51000 Rijeka, Hrvatska

2 Sveučilište u Splitu, Pomorski fakultet

Ruđera Boškovića 37, 21000 Split, Hrvatska

\section{USPOREDBA VANJSKIH TROŠKOVA U MULTIMODALNOM TRANSPORTNOM LANCU PRIJEVOZA KONTEJNERA}

\section{SAŽETAK}

U radu se razmatra multimodalni prijevoz kontejnera glede ušteda na vanjskim troškovima. Relevantni podaci analizirani su na temelju dosadašnjih istraživanja i objavljenih radova. Rezultati istraživanja pokazuju kako nema značajne razlike $u$ udjelima vanjskih troškova $u$ kontejnerskom transportu i transportu drugih vrsta tereta $u$ velikim europskim morskim lukama kao ni u potrošnji energije u tipu željeznica-unutarnje vode multimodalnog prijevoza kontejnera i rasutog tereta. Intermodalni terminali također imaju vlastite vanjske troškove. Unatoč dvostrukim željezničkim operativnim troškovima važno je da željeznička infra- i suprastruktura bude uključena u intermodalni terminal. Prijevoz tereta unutarnjim plovnim putovima ima puno veće vanjske troškove od prijevoza morem. Multimodalni prijevoz kontejnera ne smanjuje nužno vanjske troškove. Uštede su vjerojatnije ako se lokacija i vrsta intermodalnog terminala ispravno odabere $i$ ako se prijevoz morem uključi u multimodalni transportni lanac.

\section{KLUČNE RIJEČI}

multimodalni prijevoz; kontejnerski prijevoz; vanjski troškovi;

\section{REFERENCES}

[1] Ferrari C, Parola F, Gattorna E. Measuring the Quality of Port Hinterland Accessibility: The Ligurian Case. Transport Policy. 2011;18(2):382-391.

[2] Meersman H, Van de Voorde E, Vanelslander T. Future Challenges for Port and Shipping Sector. London: Informa; 2009.
[3] Tongzon JL. Port choice and freight forwarders. Transportation Research Part E. 2009;45:186-195.

[4] Jugović A, Žanić Mikuličić J, Maglić L. Impact of external costs on the implementation of Motorways of the Sea system. Scientific Journal of Maritime Research. 2014;28:17-21.

[5] Steiner S, Sapunar J, Golubić J. Prometna politika u funkciji održivog razvoja. Proceedings of the HAZU scientific conference "Nezgode i nesreće u prometu i mjere za njihovo sprječavanje"; 28 Novemberstudenoga 2007; Zagreb, Hrvatska. Zagreb: Croatian Academy of Arts and Sciences; 2007. In Croatian

[6] UIC, CER. The Way to Sustainable Mobility: Cutting the External Cost of Transport. Paris-Brussels: UICCER;2000 [cited 2016 May 03]. Available from: http:// www.railway-mobility.org/docs/uicsustainablemobility_en.pdf

[7] European Commission. The Way to Sustainable Mobility: Cutting the External Cost of Transport. Brochure of the European Commission. Brussels: European Commission; 2000.

[8] Digiesi S, Mossa G, Mummolo G. Supply Lead Time Uncertainty in a Sustainable Order Quantity Inventory Model. Management and Production Engineering Review. 2013;4(4):15-27.

[9] UNCTAD. Multimodal Transport and Trading Opportunities. UNCTAD/SDD/MT/5. Geneva: UNCTAD; 1993.

[10] European Conference of Ministers of Transport (ECMT). Terminology on combined transport. Paris: ECMT; 1993.

[11] CE Delft, Infras, Fraunhofer ISI. External Costs of Transport in Europe: Update Study for 2008. Delft: CE Delft; September 2011. Available from: http://ecocalc-test. ecotransit.org/CE_Delft_4215_External_Costs_of_ Transport_in_Europe_def.pdf

[12] Žgaljić D, Perkušić Z, Schiozzi D. Značenje multimodalnog, intermodalnog i kombiniranog prijevoza u razvoju pomorskih prometnica. Maritime Proceedings. 2015;49-50:265-279. In Croatian

[13] Heljedal M. Factors Influencing the Choice between Road and Multimodal Transportation. SE-601 74 Norrköping, Sweden: Linköping University; 2013.

[14] European Committee. A sustainable future for transport. Luxembourg: Publications Office of the European Union; 2009. doi: 10.2768/13118

[15] Branch AE. Export Practice and Management. 3rd ed. London: Chapman and Hall; 1994.

[16] Meisel F. Seaside operations planning in container terminals. Berlin: Physica; 2009.

[17] Bäck A, Kaipel M, Hartl T. Handbuch der Donauschifffahrt. Wien: Via Donau - Österr. Wasserstraßen-Ges. $\mathrm{mbH} ; 2005$.

[18] IPC. Program razvoja intermodalnog transporta u Republici Hrvatskoj [In Croatian]. Zagreb: IPC DunavJadran; 2009 Feb [last modified 2010 Sep 15; cited 2016 Mar 30]. Available from:http://www.ipc-dj.hr/ dokument/01_PROGRAM\%20RAZVOJA\%2OINTERMODALNOG\%2OPRIJEVOZA.pdf

[19] EEA, European Environment Agency. Emissions of air pollutants from transport, Convention on Long-range Transboundary Air Pollution (LRTAP Convention), United Nations Economic Commission for Europe (UNECE); 2013. [Last modified 11 Sep 2015]. Available from: 
http://www.eea.europa.eu/data-and-maps/indicators/transport-emissions-of-air-pollutants-8/transport-emissions-of-air-pollutants-9Indicator Assessment

[20] Modern Air Transport and Environment. ATR: The Optimum Choice for a Friendly Environment. CO/EM 467/00; 31712 Blagnac, France: ATR; 2001 [cited 2016 Mar 30]. Available from: http://web.fc.fi/data/ files/ATR_TheOptimumChoice.pdf

[21] Hinšt Z. Europske studije o eksternim troškovima u prometu. Ekonomski pregled. 2006;57(11):778-788. Croatian

[22] European Conference of Ministers of Transport (ECMT). Efficient Transport for Europe, Policies for Internalisation of External Costs. Paris: ECMT; 1998.

[23] Bošnjak I. Razvoj inteligentnih transportnih sustava - ITS [In Croatian]. Open Info Trend [Internet]. 2008 June [cited 2016 May 03]; 161(5):52-56. Available from: http://www.infotrend.hr/clanak/2008/6/razvoj-inteligentnih-transportnih-sustava-\%E2\%80\%93-its,14,323.html

[24] Hsu C-H, Xia F, Liu X, Wang S, editors. Internet of Vehicles - Safe and Intelligent Mobility. Proceedings of the 2nd International Conference, IOV 2015; 2015 Dec 1921; Chengdu, China. 6330 Cham, Switzerland: Springer International Publishing; 2015. doi:10.1007/978-3319-27293-1

[25] Ricardo-AEA. Update of the Handbook on External Costs of Transport, Final Report., Report for the European Commission: DG MOVE, Ricardo-AEA/R/ ED57769, Issue, Number 1; Jan 2014.

[26] OECD. External costs of transport in Central and Eastern Europe, Final report. Working Party on National Environmental Policy, Working Group on Transport; 2003 May 27-28; Paris, France. Paris: OECD; 2003.

[27] Steiner S, Badanjak D, Božičević J. External Transport Costs as Element of Planning Policy. 5th International Conference "Traffic Safety for Big Cities", Proceedings, Supplement / Gorev AE. (ed.). St Petersburg, Russia: St Petersburg State University of Architecture \& Civil Engineering; 2002. p. 1-8.

[28] Maibach M, editor. External Costs of Transport, Accident, Environmental and Congestion Costs in Western Europe. Paris: The International Union of Railways; 1999.

[29] Wei Y. Research on Intermodal External Costs of International Container. Proceedings of the 2016 2nd International Conference on Education Technology, Management and Humanities Science (ETMHS 2016). 2016 Jan 23-24; Beijing, China. Amsterdam - Beijing Paris: Atlantis Press; 2016.

[30] Ortolani C, Persona A, Sgarbossa F. External cost effects and freight modal choice: research and application. International Journal of Logistics Research and Applications. 2011;14(3):199-220. doi.org/10.1080/ 13675567.2011.609536

[31] Maffii S, Molocchi A, Chiffi C. External Costs of Maritime Transport [Internet]. Brussels: European Parliament; 2007 Jun [cited 2016 Mar 30]. Available from: http://www.europarl.europa.eu/activities/expert/eStudies. do? language $=\mathrm{EN}$

[32] Merk O. Shipping Emissions in Ports. International Transport Forum, Discussion Paper No. 2014-20. 2014 Dec; Paris, France. Paris: OECD Publishing; 2014
Dec [cited 2016 Mar 30]. Available from: http://www. itf-oecd.org/sites/default/files/docs/dp201420.pdf

[33] Burkhard E, Nemoto T. Intermodal Logistics Policies in the EU, the U.S. and Japan. Transport Policy Studies' Review [Internet]. 2005 [cited 2016 May 03]; 7(4):214. Available from:http://www.jterc.or.jp/kenkyusyo/ product/tpsr/bn/pdf/no27-01.pdf

[34] Janic M. Modelling the full costs of an intermodal and road freight transport network. Transportation Research Part D. 2007;12(1):33-44. doi:10.1016/j. trd.2006.10.004

[35] Rožić T, Petrović M, Ogrizović D. Container transport flows as a prerequisite for determination of inland terminal location. Scientific Journal of Maritime Research 2014;28(1):3-9.

[36] Kotowska I. Method of Assessing the Impact of Polish Container Terminals in Reducing the External Costs of Transport. Promet-Traffic \& Transportation. 2013;25(1):73-80. doi: doi.org/10.7307/ptt. v25i1.1249

[37] NEA, CE Delft, PLANCO, MDS Transpodaal, Via Donau. Medium and long term perspectives of IWT in the European Union, Final Report. Study commissioned by the European Commission-DG Mobility and Transport. Zoetermeer, Holland: NEA; 2011.

[38] Caris A, Limbourg S, Macharis C, Van Lier T, Cools M. Integration of inland waterway transport in the intermodal supply chain: a taxonomy of research challenges. Journal of Transport Geography. 2014;41:126-136.

[39] PLANCO Consulting GmbH, Bundesanstalt für Gewässerkunde.Verkehrswirtschaftlicher und ökologischer Vergleich der Verkehrsträger Straße, Schieneund Wasserstraße. Study performed for Wasser-und Schiffahrtsverwaltung des Bundes, Final report. Essen, Germany: PLANCO; 2007. German

[40] Meersman H, Monteiro F, Pauwels T, Van de Voorde E, Vanelslander T. Marginal cost pricing in sea ports: how to model and assess differences between ports? Proceedings of the European Transport Conference (ETC). 2007 Oct 17-19; Leiden, the Netherlands. Leiden: AET; 2007.

[41] Sulbaran T, Sarder MD. Logistical Impact of Intermodal Facilities. Proceedings of 2013 ASEE Southeastern Section Annual Conference and Meeting. 2013 Mar 10-12; Cookeville, Tennessee. Washington: American Society for Engineering Education; 2013.

[42] Rudolf CD. A cost Comparison of Modern Container Cranes. In: Knott MA, editor. Ports '95. Proceedings de la Conferencia: Ports`95. 1995 Mar 13-15; Tampa, Florida. New York: American Society of Civil Engineers; 1996.

[43] Abbes S. Marginal social cost pricing in European seaports. European Transport \ Trasporti Europei. 2007;36:4-26.

[44] Notteboom T, Rodrigue JP. Containerization, box logistics and global supply chains: the integration of ports and liner shipping networks. Maritime Economics and Logistic. 2008;10:152-174.

[45] Ambrosino D, Ferrari C, Sciomachen A, Alessio T. Intermodal nodes and external costs: re-thinking the current network organization. Proceedings of the World Conference on Transport Research (SIG 2WCTR). 2015 May 11-12; Antwerp, The Netherlands. 
Antwerp: University of Antwerp; 2015 May [cited 2016 Mar 30]. Available from:http://imet.gr/Portals/0/Intranet/Proceedings/SIGA2/tei[1].pdf

[46] Bojic S, Brcanov D, Georgijevic M, Zrnic N. Location Problem of Container Terminals - an Internal and
External Costs Approach. Proceedings of 27th European Conference on Operational Research. $2015 \mathrm{Ju}$ 12-15; Glasgow, UK. Lyngby, Denmark: Technical University of Denmark; 2015. Available from: http://orbit. dtu.dk/files/116531513/program_euro27.pdf 